\title{
Perfusion and ventilation of isolated canine lungs
}

\author{
T. J. OT T O, M. TRENKNER,A. ST OPCZYK, M. G A W D Z IŃSKI, \\ AND B. CHEŁSTOWSKA
}

From the Department of Thoracic and Cardiac Surgery, Institute of Tuberculosis, Warsaw, Poland ${ }^{2}$

In order to evaluate methods of preserving lungs for use in transplantation, experiments on 28 mongrel dogs were carried out. Two methods were tried-first, mechanical respiration of isolated lungs under deep hypothermia, with the vascular bed filled with blood; and, secondly, the perfusion of isolated lungs with the aid of a modified DeWall's apparatus. Allogenic transplantations of lungs preserved in both ways were carried out. Gasometric and histological examinations of preserved lungs, before and after transplantation, were performed. The best results were obtained with perfusion under hypothermic conditions; ventilation without perfusion resulted in failure. Lung transplantation was successful when, after being preserved, the lung remained unchanged. Major discrepancies between the macroscopic and microscopic findings in preserved lungs were observed. An original classification of the changes occurring in preserved lungs is proposed.

The perfusion of animals' lungs, either isolated or in situ in the pleural cavity but observed directly through a thoracotomy, was first introduced in the forties (Duke, 1949). At that time mainly physiopathological changes were observed without any attempt to introduce this method for clinical use. In the fifties the perfusion of animals' lungs became more popular due to the development of extracorporeal circulation (Lillehei and DeWall, 1958). Direct observation of the isolated lung became useful in the study of physiopathological changes occurring in human lungs during heart-lung bypass and helped to explain the mechanisms of pulmonary complications, which were common in the early stages of this procedure. Some experiments were also performed using isolated lungs as biological oxygenators for heart-lung machines (Campbell, Crisp, and Brown, 1956; Potts, Riker, DeBord, and Andrews, 1952). This method was abandoned.

In the sixties the transplantation of canine lungs became of interest in many centres (Blumenstock, Hechtman, and Collins, 1962 ; Hardy, Eraslan, and Webb, 1964 ; Largiadèr, Manax, Lyons, and Lillehei, 1966) and good results were obtained. For lung transplantation in man lungs must be satisfactorily preserved. Lungs can be kept for approximately two hours in a temperature of $39-41^{\circ} \mathrm{F}$. $\left(4-5^{\circ}\right.$ C. $)$ provided that the vascular

1Present address: Cardio-thoracic Unit, Hammersmith Hospital, London, W.12

2Instytut Gruzlicy Warszawa, ul. Plocka 26, Poland bed has been washed clear of blood and the lung has been inflated (Hardy et al., 1964). However, for practical use this period was often too short.

From a theoretical point of view, the perfusion of isolated lungs ought to permit longer preservation and protect the perfused lung from the undesirable changes which occurred in lungs preserved by other means (Marchioro, Huntley, Waddell, and Starzl, 1963).

The goal of our experiments was to elaborate a simple method of preserving lungs as well as to establish the pathological changes that occur in preserved lungs after a lapse of time. Such a method should permit preservation of lungs for a few hours and eventually the use of these lungs as allogenic transplants.

\section{MATERIAL}

Experiments were performed on 28 mongrel dogs of different ages and weights. Three groups of experiments were carried out:

1. Mechanical ventilation of isolated lungs under deep hypothermia, with or without arterial infusion. 2. Perfusion of isolated lungs under moderate hypothermia, using a modified DeWall apparatus.

3. Transplantation of lungs, preserved in both ways, to unrelated recipients.

GROUP 1 Experiments were performed on 10 dogs. These were anaesthetized with pentothal and intubated, following which controlled respiration was carried out with the use of Waters' absorber. The 


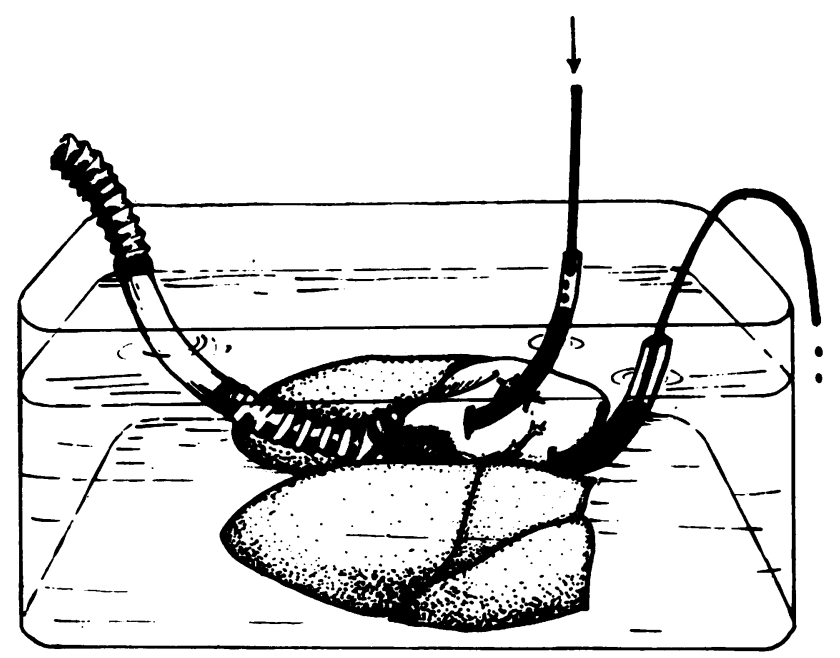

FIG. 1. Specimen consisting of both lungs and heart preserved by means of ventilation and hypothermia. Cannula inserted into outflow tract of right ventricle and into left atrium. Intraarterial drip and syphon-drainage are employed. In order to keep the lungs submerged, they were weighted down.

chest was opened by a transverse incision with sternotomy. The aorta, venae cavae, and trachea were dissected, and tapes were put around the dissected vessels but at that stage were not tied. The dogs were heparinized and bled from the femoral artery, blood being collected for further use. As the bleeding stopped, large vessels were occluded, the trachea was severed, and a specimen consisting of both lungs and the heart was taken. The trachea was intubated, and controlled respiration was continued. Subsequently, the main pulmonary artery was cannulated through a transverse incision in the outlet of the right ventricle. Another cannula of bigger lumen was inserted through the left ventricle and mitral valve into the left atrium. Both cannulae were secured and tied by double purse strings.

The specimen was then placed in a glass container filled with physiological solution and ice, special attention being paid to ensure that both lungs were completely covered by the solution (Fig. 1). Controlled respiration was maintained using Waters' absorber and 'Pulmomat' (produced by Dräger), the rate of respiration being $12 /$ minute, inspiration pressure $+10 \mathrm{~cm}$. water, and expiration -2 to $-4 \mathrm{~cm}$. water.

In some of these experiments intra-arterial infusion of blood or blood diluted with Macrodex was used with the help of an ordinary drip. In these cases syphon-drainage of the venous blood was also applied. Care was taken to ensure that the blood level in the arterial cannula never exceeded $12 \mathrm{~cm}$., and in the atrial cannula $5 \mathrm{~cm}$., from the mean level of the left atrium. The flow was approximately $20 \mathrm{ml}$./ minute.

In the remaining experiments no infusion was applied, but the pulmonary vascular bed and both cannulae were filled with blood. Here the cannulae played the part of fluid reservoirs. It was assumed that the capillary flow would be maintained by ventilatory movements of the lungs.

In all experiments very fine polyethylene catheters were inserted through both cannulae and wedged in precapillary vessels, enabling the collection of blood samples and gasometric examinations.

Lungs were preserved in the described manner for 2 to 16 hours in a temperature of $37-41^{\circ} \mathrm{F}$. $\left(3-5^{\circ} \mathrm{C}\right.$.). Changes occurring in the lungs were noted by direct observation as well as by taking hourly biopsies, which were subsequently examined histologically (Table I).

GROUP 2 Experiments were carried out on 12 dogs which were anaesthetized and operated upon as in the first group.

After having the specimen cannulated and the vascular bed and both cannulae filled with Macrodex, it was attached to our own modification of DeWall's apparatus, and a perfusion with blood or blood diluted with Macrodex was maintained for 2 to 24 hours (Lillehei and DeWall, 1968) (Fig. 2).

The main parts of the apparatus were (A) bubble oxygenator, (B) decompensating chamber, (C) spiral, (D) venous blood reservoir, (E) arterial pump, (F) heat exchanger. The specimen $(\mathrm{H})$ was kept on a high level so that gravity drainage of the venous blood was feasible. Oxygen was supplied to the oxygenator through a plastic filter providing good dispersion of oxygen and protection from a reflux of blood into the catheter in case the oxygen flow was stopped. The flow of 21 . oxygen per minute was adequate to lift the foamed blood into the decompensating chamber. This was tightly filled with polyethylene fibres. This chamber served to separate the excess oxygen from the arterialized blood. Subsequently, blood flowed by gravity into the polyvinyl spiral, where the effective removal of free oxygen remaining in the blood 
T A B L E I

LUNGS PRESERVED UNDER DEEP HYPOTHERMIA WITH MECHANICAL VENTILATION

\begin{tabular}{|c|c|c|c|c|c|c|c|c|c|}
\hline $\begin{array}{l}\text { Dog } \\
\text { No. }\end{array}$ & $\begin{array}{l}\text { Preser- } \\
\text { vation } \\
\text { (hours) }\end{array}$ & $\begin{array}{l}\text { Temp. } \\
\text { of } \\
\text { Lungs } \\
\left({ }^{\circ} \mathrm{C} .\right)\end{array}$ & $\begin{array}{l}\text { Minute } \\
\text { Flow } \\
\text { (ml.) }\end{array}$ & $\begin{array}{c}\text { Arterial } \\
\text { Pressure } \\
\left(\mathrm{ml} . \mathbf{H}_{\mathbf{2}} \mathbf{O}\right)\end{array}$ & Perfusate & $\begin{array}{l}\text { Clinical } \\
\text { Group }\end{array}$ & $\begin{array}{c}\text { Onset } \\
\text { of } \\
\text { Oedema } \\
\text { (hours) }\end{array}$ & $\begin{array}{c}\text { Onset of } \\
\text { Extra- } \\
\text { vasations } \\
\text { (hours) }\end{array}$ & $\begin{array}{l}\text { Histopathological Changes revealed } \\
\text { after Conclusion of Experiment }\end{array}$ \\
\hline 11 & 14 & $4-5$ & - & - & & 3 & 一 & 4 & Emphysema, extravasations, slight \\
\hline $\begin{array}{l}12 \\
13 \\
15 \\
17 \\
20\end{array}$ & $\begin{array}{r}2 \\
10 \\
6 \\
10 \\
6\end{array}$ & $\begin{array}{l}4-5 \\
5 \\
5 \\
5 \\
2\end{array}$ & $\frac{\overline{20}}{15-20}$ & $\begin{array}{l}\overline{-} \\
\frac{6-8}{6-8}\end{array}$ & $\begin{array}{l}\text { Blood } \\
\text { Blood } \\
\text { Blood } \\
\text { Blood } \\
\text { Blood : Macrodex } \\
4: 1\end{array}$ & $\begin{array}{l}2 / 3 \\
2 / 3 \\
2 \\
2 / 6 \\
3\end{array}$ & $\begin{array}{r}2 \\
6 \\
5 \\
6 \\
-\end{array}$ & $\frac{2}{7}$ & $\begin{array}{l}\text { Oedema, extravasations, emphysema } \\
\text { Oedema, congestion, emphysema } \\
\text { Slight oedema } \\
\text { Slight oedema, extravasations } \\
\text { Congestion, extravasations }\end{array}$ \\
\hline $21^{1}$ & 5 & 3 & 10 & 13 & Blood : Macrodex & 1 & - & - & $\begin{array}{l}\text { Slight congestion otherwise normal } \\
\text { tissue }\end{array}$ \\
\hline $23^{1}$ & 5 & 3 & 5 & $6: 8$ & $\begin{array}{c}\text { Blood : Macrodex } \\
5: 1\end{array}$ & 1 & - & - & Normal pulmonary tissue \\
\hline 27 & 6 & 3 & 10 & 10 & $\begin{aligned} & \text { Blood : } \text { Macrodex } \\
& 5: 1\end{aligned}$ & 1 & - & 一 & Normal pulmonary tissue \\
\hline 28 & 5 & 4 & 8 & 6 & $\begin{array}{c}\text { Blood : Macrodex } \\
5: 1\end{array}$ & 2 & 5 & - & Oedema \\
\hline
\end{tabular}

${ }^{1}$ Lungs used for transplantation.

FIG. 2. Modified DeWall's apparatus for perfusion of isolated canine lungs. See text.

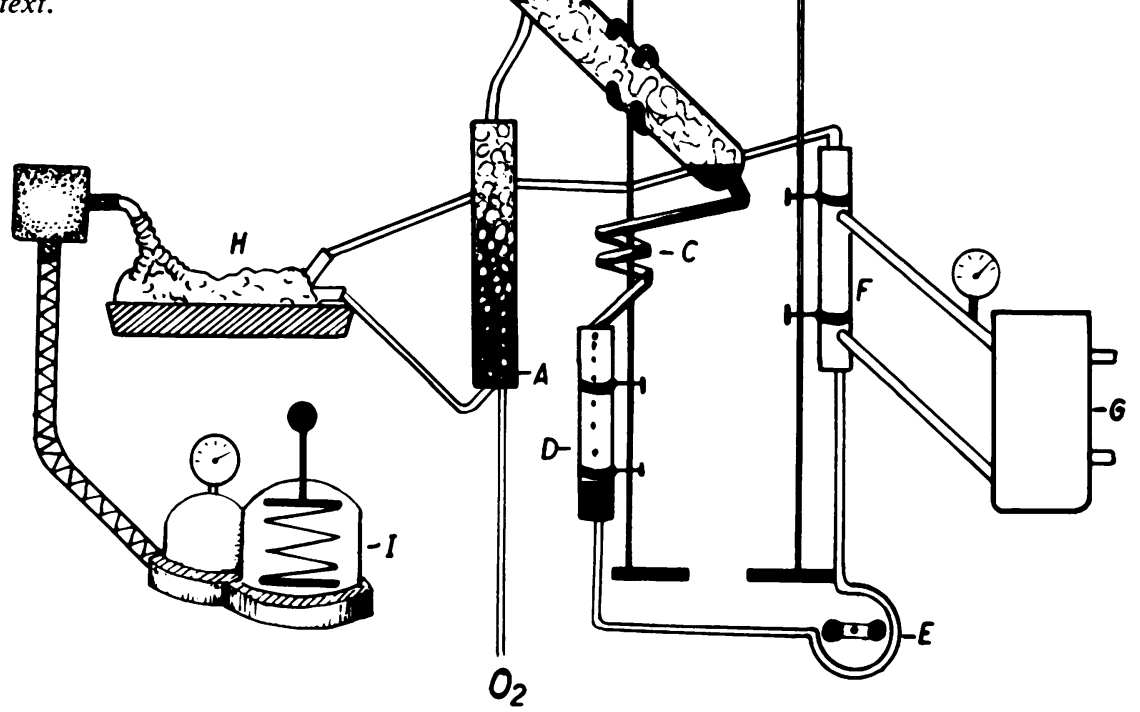

was achieved. After leaving the spiral, blood was pumped through a heat exchanger into an arterial cannula in the preserved specimen (H in Fig. 2). We used two different arterial pumps, at first the Sigma pump which was excellent, but later, due to damage, this was replaced by a rotating pump produced in our own workshop, which was not quite as good and caused some haemolysis.

The heat exchanger was cooled by circulating water, which itself was cooled by indirect contact with dry ice in a special container ( $G$ in Fig. 2).

The apparatus supplied a minute flow of 50 to $250 \mathrm{ml}$. with full oxygenation of the blood. The mean arterial gasometry was: $p \mathrm{H} 10 \cdot 87 \pm 1 \cdot 2, \quad \mathrm{Po}_{2}$ $840 \pm 92, \mathrm{PCO}_{2}-0$.

The preserved lungs were also ventilated by 'Pulnomat' ( $\mathrm{I}$ in Fig. 2). Ventilation was maintained, as it was considered to be a mechanical factor having great influence on the capillary circulation.

During perfusion the lung temperature ranged from 48 to $73^{\circ} \mathrm{F}$. (9 to $23^{\circ} \mathrm{C}$.), the minute flow from 50 to $100 \mathrm{ml} . / \mathrm{min}$., and initial arterial pressure from 11 to $25 \mathrm{~mm}$. $\mathrm{H}_{2} \mathrm{O}$.

Changes in the lungs were noted by direct observation and histological examination. Blood gas analysis was also carried out (Table II). 
T A B L E I I

LUNGS PRESERVED BY PERFUSION

\begin{tabular}{|c|c|c|c|c|c|c|c|c|c|}
\hline $\begin{array}{l}\text { Dog } \\
\text { No. }\end{array}$ & $\begin{array}{l}\text { Per- } \\
\text { fusion } \\
\text { (hours) }\end{array}$ & $\begin{array}{c}\text { Temp. } \\
\text { of } \\
\text { Lungs } \\
\left({ }^{\circ} \mathrm{C} .\right)\end{array}$ & $\begin{array}{c}\text { Minute } \\
\text { Flow } \\
\text { (ml.) }\end{array}$ & $\left|\begin{array}{c}\text { Arterial } \\
\text { Pressure } \\
\left(\mathrm{ml} . \mathrm{H}_{2} \mathbf{O}\right)\end{array}\right|$ & Perfusate & $\begin{array}{l}\text { Clinical } \\
\text { Group }\end{array}$ & $\begin{array}{c}\text { Onset } \\
\text { of } \\
\text { Oedema }\end{array}$ & $\begin{array}{c}\text { Onset of } \\
\text { Extra- } \\
\text { vasations }\end{array}$ & $\begin{array}{l}\text { Histopathological Changes revealed } \\
\text { after Conclusion of Experiment }\end{array}$ \\
\hline 1 & 24 & 15 & 70 & - & Blood : glucose & 4 & 1 & - & Gross oedema, emphysema \\
\hline 2 & 18 & 9 & 100 & 一 & Blood : Macrodex & 2 & 5 & - & Oedema, emphysema \\
\hline 3 & 12 & 10 & 80 & - & Blood : Macrodex & $2 / 4$ & 5 & 5 & Extravasations, moderate oedema \\
\hline 4 & 5 & 11 & 60 & 12 & $\begin{aligned} \text { Blood }: \text { Macrodex } & \\
9 & : 1\end{aligned}$ & 1 & 一 & - & Normal pulmonary tissue \\
\hline 5 & 7 & 15 & 50 & 15 & Blood : Macrodex & $2 / 3$ & $4 \cdot 5$ & 4 & Moderate oedema, extravasations \\
\hline $6^{1}$ & 5 & 15 & 70 & 17 & Blood : Macrodex & 1 & 一 & - & Normal pulmonary tissue \\
\hline $8^{1}$ & $2 \cdot 5$ & 20 & 80 & 25 & 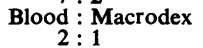 & $2 / 3$ & 1 & 1 & Oedema, singular extravasations \\
\hline 10 & $3 \cdot 5$ & 18 & 50 & 15 & $\begin{aligned} & \text { Blood : Macrodex } \\
& 1: 1\end{aligned}$ & $2 / 3$ & 3 & 3 & $\begin{array}{l}\text { Oedema, multiple focular extravasa- } \\
\text { tions }\end{array}$ \\
\hline $\begin{array}{l}14 \\
18^{1}\end{array}$ & 2 & $\begin{array}{l}23 \\
18\end{array}$ & $\begin{array}{l}60 \\
60\end{array}$ & $\begin{array}{l}18 \\
13\end{array}$ & $\begin{array}{l}\text { Blood } \\
\text { Blood : Macrodex } \\
9: 1\end{array}$ & $2 / 3$ & 2 & $\begin{array}{l}1 \cdot 5 \\
2 \cdot 5\end{array}$ & $\begin{array}{l}\text { Congestion and oedema } \\
\text { Congestion, multiple focular extra- } \\
\text { vasations }\end{array}$ \\
\hline 25 & 2 & 22 & 100 & 22 & $\begin{aligned} & \text { Blood : Macrodex } \\
& 1: 1\end{aligned}$ & 2 & 2 & - & Slight oedema \\
\hline 29 & 4 & 16 & 80 & 12 & $\begin{aligned} \text { Blood : Macrodex } & \\
9 & : 1\end{aligned}$ & 5 & 4 & $2 \cdot 5$ & Singular extravasations \\
\hline
\end{tabular}

Lungs used for transplantation.

GROUP 3 Six experimental transplantations were performed. In each case one of the preserved lungs was transplanted into an unrelated recipient. The technique of transplantation had been developed in previous experiments (Otto and Trenkner, 1966 ; Otto, 1967), and the same technique was employed in this series. The transplanted lungs were not selected, therefore varying degrees of damage due to preservation were already present. Transplantation was to prove whether or not a lung with pathological changes stood any chance of being accepted.

After transplantation had been completed, gasometric examination was carried out in all cases. Survival of the animals was attempted and, in order to minimize immunological reaction, methotrexate in a dose of $0.2 \mathrm{mg} . / \mathrm{kg}$. body weight was administered. During the post-operative course radiological examinations were carried out, including angiography. The animals that died were submitted to necropsy (Table III).

\section{RESULTS AND DISCUSSION}

In order to estimate the results of the changes that occurred in the perfused lungs, a division into five clinical groups was adopted. This was based partly on Veith's classification (Veith, Deysine, Nehlsen, and Karl, 1966 ; Veith, Hagstrom, Nehlsen, Kahl, and Deysine, 1967), which in itself was not satisfactory because it took only anatomical factors into consideration. The classification below appears to us to be more suitable for clinical use.

\section{CLINICAL GROUPS OF PERFUSED AND} VENTILATED CANINE LUNGS

Group 1 Lungs are of normal colour, collapsing completely when detached from the respirator and not changing colour.

Group 2 Lungs retain normal colour but do not collapse completely when detached from the respirator. On palpation, they are harder than normal and crepitant. The bronchial tree contains a small amount of frothy secretion of normal colour.

Group 3 Lungs are of normal colour and consistency on inspiration, but on expiration they are visibly congested and red in colour. When detached from the respirator they collapse almost completely, and at that time singular, subpleural haematomas are clearly seen.

Group 4 Lungs are pinkish in colour. On palpation they are hard and crepitant. In the bronchial tree is an excessive amount of frothy red secretion. The lungs do not collapse on expiration. The total weight is greatly increased.

Group 5 Lungs on inspiration under normal pressure do not distend completely ; in some parts there remain dark pinkish or red areas. Under increased pressure the lungs distend but remain 
T A B L E I I I

RESULTS OF TRANSPLANTATION OF PRESERVED LUNGS

\begin{tabular}{|c|c|c|c|c|c|c|c|}
\hline \multirow{2}{*}{ Dog No. } & \multirow{2}{*}{ Method of Preservation } & \multirow{2}{*}{$\begin{array}{l}\text { Time from } \\
\text { Collecting } \\
\text { Lung until } \\
\text { Implanta- } \\
\text { tion (hours) }\end{array}$} & \multirow{2}{*}{$\begin{array}{l}\text { Clinical } \\
\text { Group }\end{array}$} & \multicolumn{3}{|c|}{$\begin{array}{c}\text { Function of Lung after Implantation } \\
\text { as Estimated by Gasometry }\end{array}$} & \multirow{2}{*}{ Final Result } \\
\hline & & & & & $\begin{array}{l}\text { Blood from } \\
\text { Pulm. Artery }\end{array}$ & $\begin{array}{l}\text { Blood from } \\
\text { Pulm. Veins }\end{array}$ & \\
\hline \multirow{3}{*}{7} & \multirow{3}{*}{ Perfusion } & \multirow{3}{*}{$5 \cdot 5$} & \multirow{3}{*}{1} & $p \mathrm{H}$ & $7 \cdot 40$ & $7 \cdot 47$ & \multirow{3}{*}{ Long-term survival } \\
\hline & & & & $\mathrm{PO}_{2}$ & 50 & 485 & \\
\hline & & & & $\mathrm{PCO}_{2}$ & 25 & 22 & \\
\hline 16 & $\begin{array}{c}\text { Mechanical ventilation } \\
\text { under hypothermia }\end{array}$ & 7 & 2 & $\begin{array}{l}\text { Oxygen } \\
\text { saturation }\end{array}$ & $72 \%$ & $99 \%$ & $\begin{array}{l}\text { Died on second day due to } \\
\text { pulmonary oedema }\end{array}$ \\
\hline \multirow{3}{*}{22} & \multirow{3}{*}{$\begin{array}{l}\text { Mechanical ventilation } \\
\text { under hypothermia }\end{array}$} & \multirow{3}{*}{$5 \cdot 5$} & \multirow{3}{*}{1} & $p H$ & $7 \cdot 41$ & $7 \cdot 47$ & \multirow{3}{*}{$\begin{array}{l}\text { Died on eighth day due to } \\
\text { interstitial changes }\end{array}$} \\
\hline & & & & $\mathrm{PO}_{2}$ & 56 & 480 & \\
\hline & & & & $\mathrm{PCO}_{2}$ & 24 & 21 & \\
\hline \multirow{3}{*}{24} & \multirow{3}{*}{$\begin{array}{l}\text { Mechanical ventilation } \\
\text { under hypothermia }\end{array}$} & \multirow{3}{*}{$5 \cdot 5$} & \multirow{3}{*}{1} & $p \mathbf{H}$ & $7 \cdot 36$ & $7 \cdot 40$ & \multirow{3}{*}{$\begin{array}{l}\text { Died on sixth day due to } \\
\text { interstitial changes }\end{array}$} \\
\hline & & & & $\mathrm{PO}_{2}$ & 52 & 520 & \\
\hline & & & & $\mathrm{PCO}_{2}$ & 26 & 22 & \\
\hline 9 & Perfusion & 3 & $2 / 3$ & - & - & - & $\begin{array}{l}\text { Died on second day due to } \\
\text { pulmonary oedema }\end{array}$ \\
\hline \multirow{3}{*}{19} & \multirow{3}{*}{ Perfusion } & \multirow{3}{*}{$4 \cdot 5$} & \multirow{3}{*}{3} & $p \mathrm{H}$ & $7 \cdot 38$ & $7 \cdot 45$ & \multirow{3}{*}{$\begin{array}{l}\text { Died on fourth day due to } \\
\text { interstitial changes }\end{array}$} \\
\hline & & & & $\mathrm{Po}_{2}$ & 60 & 520 & \\
\hline & & & & $\mathrm{PCO}_{2}$ & 24 & 22 & \\
\hline
\end{tabular}

dark pink. On expiration they do not collapse ; they are hard on palpation and dark red ; in some parts they are almost black.

Only lungs belonging to the first group can be considered 'normal'. Conventional histological examination shows no changes in these lungs, and normal gas exchange takes place.

Lungs of the second and fourth groups are oedematous in varying degrees, oedema being the result of severe damage to the alveolo-capillary membrane.

In some lungs the changes included in groups 3 and 5 occurred alone, and at other times they were the dominant features. Histological examination of these lungs revealed blood cells outside the vascular bed, corresponding to the interstitial extravasations, which were seen clinically.

From our experiments we deduced that the preservation of lungs using ventilation and deep hypothermia was not satisfactory. In such lungs haemorrhagic changes were uncommon and oedematous secretion was often not noticeable; but when examined histologically, oedema was almost always revealed. It is worth stressing here that, in order to find oedematous changes in small biopsy specimens, the latter have to be submerged immediately in hot formaldehyde ; otherwise no oedema may be found.

The use of intra-arterial blood infusion did not lessen the incidence of oedema but increased the tendency to haemorrhagic changes. The best results were obtained when blood, diluted with Macrodex, was used for infusion. In three cases the lungs were kept for four to five hours and could then be classified as being in the first group. However, in two instances these lungs developed alveolo-capillary blocks on the second and third days after transplantation.

Blood samples taken from the precapillary vessels in all lungs preserved by ventilation and hypothermia showed a $p \mathrm{H}$ of $7 \cdot 30$ to $7 \cdot 48, \mathrm{Po}_{2}$ 380 to 670 , and $\mathrm{PCO}_{2}$ approximately 0 . This proved that the oxygenation of the blood in lungs thus preserved was good and that the oedema and alveolo-capillary block which later developed could have resulted only from poor perfusion and from blood in the capillary bed. These complications proved that ventilatory lung movements did not, in themselves, supply a good enough pumping action to maintain proper capillary circulation.

In the second group of experiments, when perfusion was employed, the results were better. In seven out of twelve cases the lungs were kept for four hours without oedema.

Although perfusion of the isolated lung was more physiological than ventilation alone, these lungs were still not 'normal'. The arterial blood flow was continuous and not pulsating, and the arterial blood when entering the vascular bed was 
already oxygenated and did not contain $\mathrm{CO}_{2}$. There was no vegetative nervous system correlating the action of the perfusing and ventilating systems. It is difficult to determine which factor was responsible for the fact that preserved lungs did not retain normal function for longer periods. On the basis of clinical observations of the occurrence of oedema in both man and animals, we suggest that a lack of correlation between perfusion and ventilation may be responsible.

The first sign of oedema was usually the increase in resistance and pressure in the pulmonary artery, and almost simultaneously the increase in respiratory resistance, clearly visible on the manometer. At that time, the lung often appeared normal, but biopsy revealed various degrees of oedema. Shortly afterwards the loss of perfusate became evident, and frothy bronchial secretion appeared. These signs increased and in the final stages, in lungs kept for 24 hours, the escape of perfusate into the bronchial tree amounted to as much as $50 \%$ of minute flow.

The minute flow and the pressure on both the arterial and venous sides greatly influence the occurrence of oedema. Despite the fact that under normal conditions the pulmonary flow is high, being equal to the systemic flow, in the isolated lung this flow has to be considerably less. In order to produce, under experimental conditions, a pulmonary minute flow equal to that of a living animal, a high arterial pressure is required ; this inevitably leads to damage of the capillaries and interstitial haemorrhages. Due to this fact, in our experiments we were producing such minute flows as were necessary to maintain the normal appearance of the lung, which was being determined both macroscopically and microscopically. It was possible to preserve the normal lung appearance within arterial pressures of 15 to 22 $\mathrm{cm} . \mathrm{H}_{2} \mathrm{O}$, the minute flows being $50-100 \mathrm{ml}$.

The temperature influenced the onset of oedema importantly. We found that the optimal temperature was $59^{\circ} \mathrm{F}$. $\left(15^{\circ} \mathrm{C}\right.$.), and that above $71.5^{\circ} \mathrm{F}$. $\left(22^{\circ}\right.$ C. $)$ oedema occurred rapidly.

Another common complication besides oedema was the occurrence of interstitial extravasations. Singular, perivascular, and subpleural extravasations can appear as a result of local damage to the fine vessels, usually caused by an increase in venous pressure in some part of the lung. Such an increase in pressure is usually due to improper positioning of the lung, making venous drainage from a segment or lobe difficult. Generalized interstitial extravasations involving the whole lung resulted from severe damage to the alveolar-capil- lary membrane. In the first stage of such damage, only oedema was present, later on, and parallel with the increasing number of blood cells escaping through these membranes, extravasations occurred.

One of the causes of generalized interstitial os extravasations was faulty cannulation or perfu- $\overrightarrow{0}$ sion, which caused an increase in venous pressure.

The composition of the perfusate influenced $\vec{\omega}$ the occurrence of both oedema and haemorrhages. When fresh blood alone was used for per- $\times$ fusion, oedema appeared relatively late, usually $\underset{\omega}{N}$ after the occurrence of congestion and extravasations. The latter appeared more rapidly than when blood diluted with Macrodex was used. The greater the dilution of blood, the earlier the oedema occurred, and the extravasations. Low molecular fluids were unsuitable for dilution, they caused immediate oedema.

Transplantation of lungs in these experiments was meant as a final criterion of the adequacy $\mathbb{\complement}$ of preservation. Lungs belonging to various $\vec{\varphi}$ clinical groups were transplanted. It was proved $\odot$ that lungs even slightly oedematous or affected in other ways stood no chance of performing a normal function. This was so despite the fact that some dogs were treated for several hours after transplantation as human beings suffering from $\stackrel{\circ}{\Phi}$ pulmonary oedema. Although the oedema appeared to be controlled, the final result was invariably fatal.

The main reason for failure after transplantation of lungs belonging to the first group, thus considered to be undamaged, was alveolo-capillary block occurring on the second or third days. As mentioned previously, this was probably due to insufficient capillary flow during preservation. In two instances directly after implantation these lungs showed a relatively low $p \mathrm{H}$ value, with a $\frac{3}{3}$ normal $\mathrm{PO}_{2}$ and $\mathrm{PCO}_{2}$, which could only have been due to metabolic acidosis following insufficient perfusion.

One of the recipients of a transplanted lung that had previously been perfused for five hours is $N$ alive 16 months later, and the lung maintains $N$ a normal function. This proves that when ideal $N$ minute flows, pressure, and ventilation are main- $\omega$ tained the lung can retain a normal function after prolonged preservation.

The imperfection of the described method of preserving lungs lies in the difficulty of a proper: choice of these parameters.

Our thanks are due to Professor S. Chodkowska and Dr. A. Koziorowski for permission to carry out $\stackrel{\mathbb{Q}}{Q}$ histological and gasometric examinations in their $\sigma$ 
departments, respectively, and to Dr. H. Meissner for the drawings.

\section{REFERENCES}

Blumenstock, D. A., Hechtman, H. B., and Collins, J. A. (1962) Preservation of the canine lung. J. thorac. cardiovasc. Surg., 44, 771.

Campbell, G. S., Crisp, N. W., and Brown, E. B. (1956). Total cardiac by-pass in humans utilizing a pump and heterologous lung oxygenator (dog lungs). Surgery, 40, 364.

Duke. H. N. (1949). The action of carbon dioxide on isolated perfused dog lungs. Quart. J. exp. Physiol., 35, 25.

Hardy, J. D., Eraslan, S., and Webb, W. R. (1964). Transplantation of the lung. Ann. Surg., 160, 440.

Largiadèr, F., Manax, W. G., Lyons, G. W., and Lillehei, R. C. (1966). Technical aspects of transplantation of preserved lungs. Dis. Chest, 49, 1.
Lillehei, C. W., and DeWall, R. A. (1958). Design and clinical application of the helix reservoir pump-oxygenator system for extracorporeal circulation. Postgrad. Med., 23, 561 .

Marchioro, T. L., Huntley, R. T. Waddell, W. R., and Starzl, T. E. (1963). Extracorporeal perfusion for obtaining postmortem homografts. Surgery, 54, 900 .

Otto, T. J. (1967). Homologiczne przeszczepy pluc u psów. Rozprawy Wydzialu Nauk Medycznych, 1, 89.

- and Trenker, M. (1966). Homotransplantation of the lung in dogs, with special reference to the circulation system in the transplant. Thorax, 21, 564 .

Potts, W. J., Riker, W. L., DeBord, R., and Andrews, C. E. (1952). Maintenance of life by homologous lungs and mechanical circulation. Surgery, 31, 161.

Veith, F. J., Deysine, M., Nehlsen, S. L., and Karl, R. C, (1966). Preservation of pulmonary function, hemodynamics, and morphology in isolated perfused canine lungs. J. thorac. cardiovasc. Surg., 52, 437.

, Hagstrom, J. W. C., Nehlsen, S. L., Kahl, R. C., and Deysine, M. (1967). Functional hemodynamic, and anatomic changes in isolated perfused dog lungs: the importance of perfusate characteristics. Ann. Surg., 165, 267. 